\title{
Evaluation of Salacca sumatrana as soil conservation crop in South Tapanuli, North Sumatra, Indonesia
}

\author{
YUSRIANI NASUTION $^{1, \bullet}$, AZWAR RASYIDIN ${ }^{2}$, YULNAFATMAWITA ${ }^{2}$, AMRIZAL SAIDI $^{2}$ \\ ${ }^{1}$ Faculty of Agriculture, Universitas Graha Nusantara. Tor Simarsayang, Padang Sidempuan City 22733, North Sumatra, Indonesia. Tel.: +62-634-25292, \\ vemail: yusriani_nasution@yahoo.com \\ ${ }^{2}$ Faculty of Agricultural Sciences, Universitas Andalas. J1. Raya Unand, Limau Manih, Padang 25163, West Sumatra, Indonesia
}

Manuscript received: 24 November 2018. Revision accepted: 12 February 2019.

\begin{abstract}
Nasution Y, Rasyidin A, Yulnafatmawita, Saidi A. 2019. Evaluation of Salacca sumatrana as soil conservation crop in South Tapanuli, North Sumatra, Indonesia. Biodiversitas 20: 664-670. Salacca sumatrana Becc (snake fruit; or 'Salak' in local name) is a profitable commodity. Morphologically, it is characterized by low, wide canopy that is potential intercept rainfall, while its roots are able to withstand soil erosion. This study is aimed to evaluate one variety of $S$. sumatrana named "salak sidimpuan" as commodity crop soil conservation based on its capability to intercept rain and trap soil sediment in the catchment area of S. sumatrana field. The research was conducted on mineral soils at West Angkola Sub-district, South Tapanuli District, North Sumatra Province, Indonesia with an altitude of 350-880 m above sea level. The study was carried out from October 2016 until March 2017 using survey method to calculate on rainfall interception, stemflow and throughfall while measurement of sediment used evaporation method. Statistical analysis was used to observe the difference of sediment trapped on the catchment area of $S$. sumatrana agroforest and the catchment area of mixed forest using Mann-Whitney Test. The results show that rainfall interception on S. sumatrana agroforest is $74.33 \%$ of the average rainfall while the Mann-Whitney Test Sig (2-tailed) is 0.000, indicating significant difference in trapping soil sediment between S. sumatrana agroforest and mixed forest. The amount of soil erosion on the catchment of $S$. sumatrana agroforest is 15.12 ton/ha/year while the erosion on mixed forest is 194.85 ton/ha/year. Thus $S$. sumatrana plant is capable to withstand rain interception with the result that soil erosion can be held in the catchment area of $S$. sumatrana agroforest. Instead of the calculation rain interception and soil erosion, then $S$ sumatrana is classified as a soil conservation crop.
\end{abstract}

Keywords: Salacca sumatrana, soil conservation, rainfall interception, and sediment trap

\section{INTRODUCTION}

Erosion is harmful to living things on earth as it decreases the quality of natural resources, disrupts ecosystems and decreases the amount of biodiversity. Erosion should be reduced or prevented for the survival of creatures from disturbances (Yan et al. 2018). Maintaining the amount of topsoil on the surface is an important agenda in soil and water conservation activities. Soil and water conservation measures can be achieved to minimize erosion rates using various techniques. In some cases, vegetative techniques are needed to anticipate erosion and landslide events in which these efforts have been applied in various countries with very significant results (Thomas et al. 2018).

Precipitation or rainfall is the main source of water, and its role should not be ignored in the hydrology cycle in nature (Xinxiao et al. 2013). Interception is the process when rainwater falls on the surface of the vegetation then flowing into the ground, or stuck for a moment before being evaporated back into the atmosphere or being absorbed by the vegetation. Rainwater flowing from vegetation canopy into the soil surface can be through two mechanical processes, namely throughfall and stemflow. Throughfall is rainwater that falls to the ground through the leaves while stemflow is water flowing down through the tree trunk surface. According to Asdak (2004), the energy of rainfall can be reduced through interception by the canopy of plants which would be able to reduce erosion hazard. Interception will effect runoff on the soil surface, reducing sediment materials that flow into lower areas or bring into the river.

Sediment yield is the amount of sediment derived from erosion occurring in the catchment area measured over certain time period and place. Sediment results are usually obtained from the measurement of accumulated sediment, or by direct measurement in the reservoir on the fraction of mineral and organic materials that are transported from various sources and deposited by air, wind, ice, or water and also include materials deposited from material floating in water or in the form of a solution (Asdak 2007).

Due to its morphological characteristics, species from Salacca genus can be used for soil conservation with diverse planting patterns. A study by Setyawan (2010) showed that the amount of erosion in the snake fruit field in Karanganyar is 8.8 tons/ha which is classified as mild erosion according to Zachar (1982). Snake fruit can be cultivated in ranges of altitude between 50 and $800 \mathrm{~m}$ above sea level (Astuti 2007). Generally, snake fruit is traditionally cultivated on the slopes, even on steep slopes. Yet, the yields remain high, and landslides rarely occurred in those areas.

Salacca sumatrana Becc (snake fruit; or 'salak' in local name) is the mascot of Padang Sidempuan City (formerly 
the capital city of South Tapanuli District), North Sumatra Province, Indonesia. Salak sidimpuan is one variety of snake fruit that is very popular because of the combination of sweet, sour and slightly bitter flavor that is typical of salak sidimpuan. These unique characteristics lead to salak sidimpuan being standout among snake fruit varieties outside Padang Sidempuan (Nasution 2015). Snake fruit, in general, is a profitable commodity to be developed because it can be intercropped with other fruit crops or trees. The canopy of this plant is relatively low and wide, so it can intercept rainfall, while its roots are able to withstand erosion. It also grows perennially throughout the year with very long productive age. Economically, the marketing of this fruit is very easy to fulfill the demands of both domestic and foreign markets (Anarsis 1996). As such, in the context of the cultivation of salak sidimpuan, this crop may be potential to mitigate erosion and landslide risks despite many advantages for local farmers as well as regional economy of Padang Sidempuan City and South Tapanuli District broadly.

Snake fruit center production area in South Tapanuli District, is located in Sub-district of West Angkola, East Angkola and Marancar with total extent of 11,874 ha and production of 340,485 tons/year (Tapsel 2015). To increase the production of salak sidimpuan, there is 15,000 ha in the region that is potential as extensification areas of snake fruit along with intensification strategy. Salak sidimpuan is also potential as soil conservation crop in South Tapanuli
District. This study is aimed to assess salak sidimpuan as soil conservation crop through collecting information on rainfall interception on the plant's body and sediment trap on catchment areas of salak sidimpuan field.

\section{MATERIALS AND METHODS}

This research was conducted in the Sub-district of West Angkola, South Tapanuli District, North Sumatra Province, Indonesia (representing the production center of snake fruit in the region)on inceptisol and entisol mineral soils 350 to $880 \mathrm{~m}$ asl. The study period was started in October 2016 and finished in March 2017. The research location is shown on the location map in Figure 1.

The materials used in this research were: administrative map with scale of 1: 50,000, land type map with scale of 1:50,000, slope map with scale of 1:50,000 and geological map scale with scale of 1:25,000.

Calculation of sediments requires river water samples and for calculation of rainfall interception a sample of rainwater, canopy water and stem water is required.

The sampled areas in this study have an extent of 1 ha for each land unit. Plant age was thirty years with spacing 3 $\mathrm{x} 3 \mathrm{~m}$ to $4 \times 5 \mathrm{~m}$ planted parallel to contour. The sampled areas is an agroforestry system with shade plants are tree crops such as durian, avocado, jackfruit, and others.

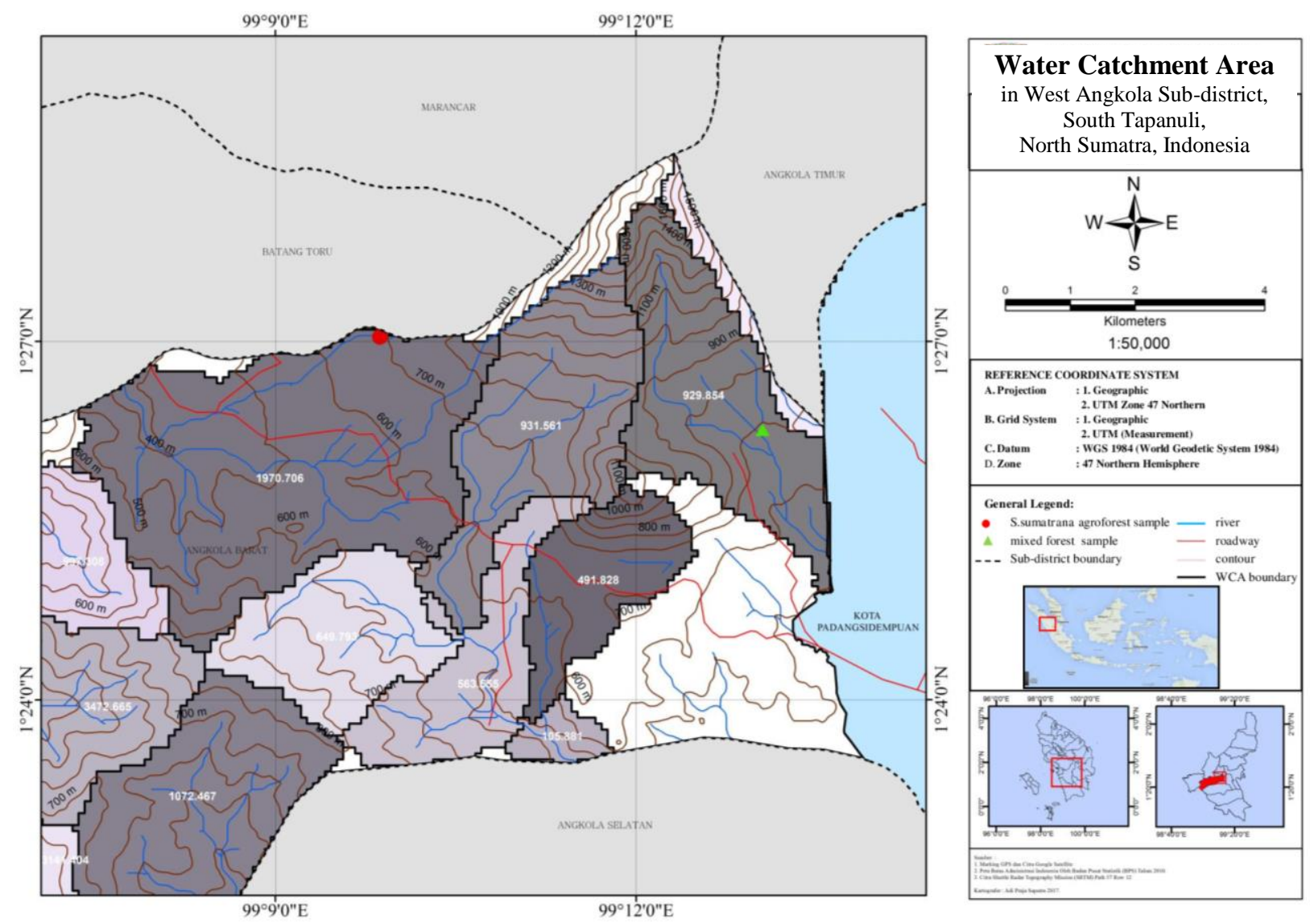

Figure 1. Map of Water Catchment Area (WCA) in landscapes with and without salak sidimpuan vegetation in West Angkola Subdistrict, South Tapanuli, North Sumatra, Indonesia 

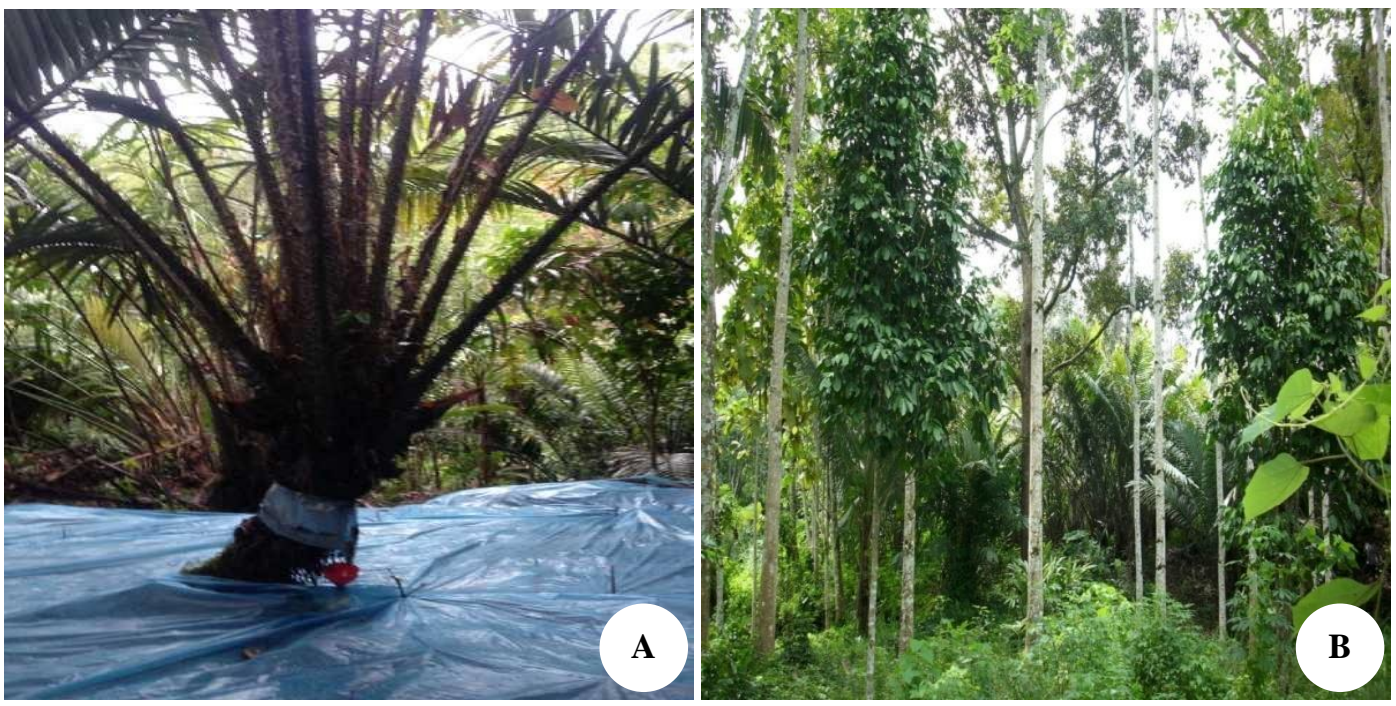

Figure 2.A. Photograph showing the method of collecting stemflow; B. Salak based agroforestry system

The equipment used were Global Positioning System (GPS), meter, plastic bags, label papers, markers, stationery as well as laboratory equipment for drying sediments and computer peripherals, container to measure stemflow, throughfall and river water samples. Photo of collection stemflow and salak based agroforestry in Figure 2.

\section{Analysis of rainfall interception}

The analysis of rainfall interception was carried out in West Angkola Sub-district of salak sidimpuan producing center by assigning five plants of snake fruit in each garden of each sub-district. The observations included measurements of rainfall, through fall water and stemflow on the plant. The magnitude of interception was calculated based on following equation:

Is $=\mathrm{R}-\mathrm{TF}-\mathrm{SF}$

with $\mathrm{R}$ refers to gross rainfall

Stemflow (SF) calculation according to Dinata (2007) was done to compare the value of stemflow between one tree and another by canopy respectively. The initial result of stemflow was obtained in unit of $\mathrm{cm}^{3}$ then it was converted into millimeters so that the following equation was used:

$\mathrm{SF}=\mathrm{X} / \pi \mathrm{r}^{2}$

SF: Stemflow $\left(\mathrm{cm}^{3}\right)$

$\mathrm{X}$ : water stored in the container $\left(\mathrm{cm}^{3}\right)$

$\mathrm{r}$ : canopy projection radius

$\pi$ : constants 3.14

The calculation of throughfall (TF) was obtained in unit of $\mathrm{cm}^{3}$ from the following equation:

$\mathrm{TF}=\mathrm{X} / \mathrm{D}$

TF: Throughfall

$\mathrm{X}$ : deep water $\left(\mathrm{cm}^{3}\right)$

D: The surface area of the container $\left(\mathrm{cm}^{2}\right)$
All calculations of stemflow, through fall and interception and the relationship between gross rainfall throughfall, stemflow, and interception were done using Microsoft Excel.

\section{Analysis of sediment trap on salak and non-salak land}

The locations of the observation point were divided into two types: (i) in river where the surrounding landscapes were planted with 'SalakSidimpuan' using agroforestry system; and (ii) in river the surrounding landscapes were not planted with salak sidimpuan .

Sediment analysis was conducted to determine the amount of sediment production and erosion rates. The amount of accumulated materials can be calculated from the relationship between the discharge and the sediment concentrations in the study area. Assuming that the sediment concentration is evenly distributed across the entire cross-sectional section of the river, the drift sediment discharges can be calculated as a result of the multiplication of sediment concentrations and flowrate and formulated as follows:

$$
\text { Qs }=\mathrm{Q} \times \mathrm{Cs} \times \mathrm{K}
$$

Qs: sediment (ton/day)

Cs: Concentration of flyover or sediment concentration $(\mathrm{mg} / \mathrm{L})$

Q: Flow debit $\left(\mathrm{m}^{3}\right)$

$$
\mathrm{K}=0.0864
$$

SDR Calculation (Sediment Delivery Ratio)

SDR is the ratio of actual sediment carried by the river to the amount of eroded soil in a watershed. The wider of a watershed there is a tendency for smaller SDR values (Kironoto 2000). The formula for calculating SDR according to Bouce (1975) is as follows:

$\mathrm{SDR}=0.41 \mathrm{~A}^{-0.3}$

SDR: Sediment Delivery Ratio

A: Wide of watershed (ha) 
The difference of sediment discharge and river discharge between two different land uses (i.e.salak agroforest versus non salak areas was tested using MannWhitney-test with SPSS software The general formula of the test with a separate sample is as follows:

$$
Z=\frac{U-\frac{n_{1} \cdot n_{2}}{2}}{\sqrt{\frac{n_{1} \cdot n_{2} \cdot\left(n_{1}+n_{2}+1\right)}{12}}}
$$

$$
\begin{aligned}
& \mathrm{Z}: \mathrm{z} \text { table } \\
& \mathrm{U}: \text { Test statistic } \\
& \mathrm{n} 1 \text { : number of sample member }
\end{aligned}
$$

\section{RESULTS AND DISCUSSION}

The morphology of salak sidimpuan is different from other species of snake fruit. Large stem, wide canopy and extensive roots can affect the interception of rainfall which can reduce surface run-off. Data of plant's height, clump and canopy area can be seen in Table 1 .

Table 1 shows that salak sidimpuan height is more than 3 meters with wide canopy areas as well as the clump diameter. The calculation of rainfall interception at the studied area in Table 2.

The result shows that the mean value of rainfall interception on salak sidimpuan plant is $74.33 \%$, indicating that this plant can withstand rainwater and reducing runoff, as such the water will go to soil through infiltration.

Rainfall interception is affected by rainfall intensity and vegetation type. This is reported by Zhang et al. (2015) that rainfall partitioning significantly differs between two shrubs with a higher stemflow production and lower interception loss for Caragana korshinskii than Artemisia ordosica. Gross rainfall, throughfall and stemflow for the two shrubs were measured during 3 growing seasons between 2011 and 2013 ina revegetated desert ecosystem in northwestern China. On average, measured throughfall, stemflow and derived interception loss for C. korshinskii $74.31 \%, 8.99 \%$ and $16.70 \%$ of the gross rainfall, respectively. Corresponding values for A. ordosica were $74.83 \%, 2.89 \%$ and $22.28 \%$, respectively. Significant differences $(\mathrm{P}<0.05)$ in stemflow and interception loss were detected between $C$. korshinskii and A. ordosica.

Rainfall partition that passing through tree canopies can be broken down into throughfall (TF), stemflow (SF), and interception loss (I) which have very significant effect on water balance and nutrient cycle. Kaushal et al. (2017) state that during the study period they conducted, there was 30 rainfall events identified in 2014 and 25 events in 2015 with delivered a total rain of $685.1 \mathrm{~mm}$ and $467.9 \mathrm{~mm}$, respectively in the two consecutive years. Average TF ranged from $80.8 \%$ in lopping to $85.1 \%$ in coppicing. Relationship of gross rainfall versus throughfall in different canopy management practices indicates that high TF production was measured during high rainfall events and low TF production was measured during low rainfall events. Average SF values showed significant difference between lopping (i.e. 10\%) and pollarding (i.e. 4.5\%) treatments. The average value of interception during 6 months can be seen in Figure 3.

Table 2shows that the highest amount of interception of rainfall in salak sidimpuan plant is in February that is equal to $79.55 \%$ while the lowest is in December with $70.87 \%$. These results were quite high if compared with other plants. For example, the interception of coffee plant with the age of 15 years is up to $72.12 \%$ (Basri et al. 2012) while the interception of pine trees in Mulan protected forests in North China region amounted is only up to $29.82 \%$ of (Liang 2014). Other examples in Bohemian forests in the Czech Republic region show that the interception value of the canopy was only $36 \%$ in 2012 and $33 \%$ of total rainfall in 2013 (Dohnal et al. 2014). Salak sidimpuan morphs is a typical plant which has a stout and large stem due to wrapped by long and prickly leaves. The leaves have length of 2.5-7.0 m which can hold rainwater falling smoothly to the ground. This characteristic causes high value of rainfall interception, reaching up to $76.23 \%$ of total rainfall on average. This is much higher than that of tropical rainforest with 35\% of total rainfall (Asdak 2007). The interception of rain is influenced by three factors including intensity and magnitude of rainfall, crop type and microclimatic conditions. Temperature, humidity, radiation and wind speed can also affect the amount of water flowing into the soil through infiltration. The high or low value of rainfall interception also depends on wind speed, leaf density, and duration of rain (Xiao et al. 2000).

Interception has a fairly close relationship with rainfall. At high intensity of rainfall, the energy of interception will decrease but when the rainfall intensity is low then the interception increase. This is in accordance with Siregar et al. (2006) which states that the capacity of interception is inversely proportional to rainfall. According to Widjajani (2010) the typology of crop for soil conservation has the characteristic of being able to catch more rain water than absorb water through infiltration.

Table 1. Plant height, stem diameter and canopy area

\begin{tabular}{ccccc}
\hline & $\begin{array}{c}\text { Height } \\
(\mathbf{m})\end{array}$ & $\begin{array}{c}\text { Stem } \\
\text { diameter } \\
(\mathbf{c m})\end{array}$ & $\begin{array}{c}\text { Canopy } \\
\text { diameter } \\
(\mathbf{m})\end{array}$ & $\begin{array}{c}\text { Canopy } \\
\text { area } \\
\left(\mathbf{m}^{\mathbf{2}}\right)\end{array}$ \\
\hline 1 & 3.1 & 90 & 5.0 & 19.63 \\
2 & 3.5 & 95 & 5.4 & 22.89 \\
3 & 3.6 & 96 & 5.6 & 24.62 \\
4 & 4 & 98 & 5.6 & 24.62 \\
5 & 4.5 & 97 & 6.0 & 28.26 \\
\hline
\end{tabular}

Table 2. The calculation of rainfall interception at studied area

\begin{tabular}{lccccccc}
\hline \multicolumn{1}{c}{ Time } & \multicolumn{2}{c}{ Rainfall } & \multicolumn{2}{c}{ Throughfall } & \multicolumn{2}{c}{ Stemflow } & \multicolumn{2}{c}{ Interception } \\
& $(\mathbf{m m})$ & $\mathbf{m m}$ & $\mathbf{\%}$ & $\mathbf{m m}$ & $\mathbf{\%}$ & $\mathbf{m m}$ & $\mathbf{\%}$ \\
\hline Oct. 2016 & 15.17 & 29.58 & 25.77 & 0.03 & 0.24 & 11.05 & 74.07 \\
Nov. 2016 & 14.11 & 35.30 & 23.04 & 0.18 & 0.85 & 10.49 & 76.20 \\
Dec. 2016 & 17.40 & 89.44 & 28.08 & 0.15 & 0.85 & 12.37 & 70.87 \\
Jan. 2017 & 9.51 & 20.00 & 25.93 & 0.05 & 0.52 & 7.04 & 73.79 \\
Feb. 2017 & 7.36 & 13.56 & 18.86 & 0.03 & 0.54 & 6.60 & 79.55 \\
Mar. 2017 & 16.15 & 18.46 & 27.24 & 0.03 & 0.22 & 11.41 & 71.49 \\
Average & & & & & & & 74.33 \\
\hline
\end{tabular}




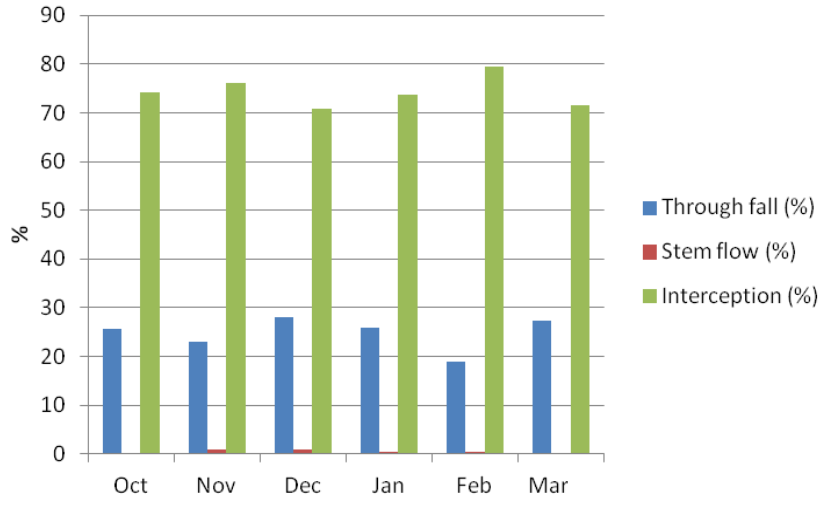

Figure 3. Interception and rainfall of West Angkola Sub-district

Salak sidimpuan have a sturdy stem, larger size, long and wide midrib leaf, and strong and deep roots. All these characteristics are potential to withstand rainwater by intercepting it strongly. This is in accordance with Anarsis (1999) that 'Salak is more muscular and larger than other types of snake fruit species and varieties. Therefore, salak sidimpuan may effectively mitigate erosion or landslides. Besides $S$ sumatrana plant as a conservation plant, it was also stated by Gaira et al. (2016) that Amomum subulatum Roxb was also cultivated with agroforestry systems as conservation plants.

\section{Analysis of sediment trap}

The calculation of sediments trap on Water Catchment Area (WCA) of in landscapes with and without salak sidimpuan vegetation in West Angkola Sub-district is presented in Table 3. The area of salak sidimpuan WCA is 2948.54 ha while the non salak sidimpuan WCA is 4872.18 ha. The WCA map of the sampling location for water can be seen in Figure 1. The results of sediment accumulated in two different catchment areas are presented in Table 3.

Table 3 shows the value of sediment in river within Water Catchment Area (WCA) in landscapes with salak sidimpuan vegetation is 14057.85 tons/day those without salak sidimpuan vegetation is 383988.00 tons/day. The value of sediment in in landscapes with salak sidimpuan vegetation is much lower than those without salak sidimpuan vegetation. We calculated that the amount of eroded soil in WCA with salak sidimpuan vegetation with the extent of 929.854 ha is 15.12 ton/ha/yr, while in WCA without salak sidimpuan vegetation with the extent of 1970.706 ha is 194.85 ton/ha/yr. Arsyad (2010) states that maximum permissible erosion is about 25 ton/ha/yr.

Cover provided by forest vegetation makes it possible to fight erosion efficiently. This is in accordance with the statement by Rey (2003) that sediment traps installed at gully outlets can distinguish between active gullies and inactive ones. The results show that gully activity is not correlated with the percentage of total vegetation cover, but with the percentage of cover of low vegetation in the gully floor instead. This is due to sediment trapping processes and highlights the importance of the spatial distribution of forest vegetation in reducing sediment yield at the gully outlet. Result on Sediment Delivery Ratio (SDR) calculation is shown in Table 4.
Table 3. The results of sediment accumulated in WCA of landscapes with and without salak sidimpuan vegetation

\begin{tabular}{lrrrrr}
\hline & \multicolumn{3}{c}{ WCA with salak } & \multicolumn{2}{c}{ WCA without salak } \\
Date & $\begin{array}{r}\text { Rainfall } \\
\text { (mm) }\end{array}$ & \multicolumn{2}{c}{ sidimpuan } & \multicolumn{1}{c}{ Qs } & \multicolumn{2}{c}{ Cs } & Qs \\
& & \multicolumn{1}{c}{ (mg/L) } & (ton/day & (mg/L) & (ton/day) \\
\hline $11-11-2016$ & 13.06 & 1200.00 & 178.89 & 1833.33 & 1132.60 \\
$12-11-2016$ & 11.15 & 650.00 & 168.48 & 234.67 & 1234.67 \\
$25-11-2016$ & 11.15 & 2566.60 & 447.10 & 7966.67 & 4336.42 \\
$26-11-2016$ & 15.29 & 3800.00 & 3939.84 & 2766.67 & 1424.28 \\
$05-12-2016$ & 8.28 & 1050.00 & 230.51 & 333.33 & 2059.20 \\
$10-12-2016$ & 8.59 & 283.33 & 62.20 & 350.00 & 2162.12 \\
$14-12-2016$ & 7.96 & 1466.67 & 321.98 & 1131667 & 4990.84 \\
$19-12-2016$ & 7.64 & 700.00 & 153.67 & 2433.33 & 1503.16 \\
$27-12-2016$ & 10.19 & 2866.67 & 1068.40 & 7916.67 & 4890.00 \\
$03-01-2017$ & 9.87 & 1700.00 & 373.21 & 3600.00 & 2223.36 \\
$04-01-2017$ & 9.55 & 2233.33 & 490.29 & 13283.33 & 4205.12 \\
$06-01-2017$ & 9.52 & 1083.33 & 237.83 & 5533.33 & 3418.00 \\
$13-01-2017$ & 11.15 & 2016.67 & 442.73 & 2583.33 & 4781.20 \\
$21-01-2017$ & 11.15 & 750.00 & 164.65 & 3700.00 & 2285.12 \\
$26-01-2017$ & 10.50 & 616.60 & 170.67 & 3800.00 & 4560.67 \\
$01-02-2017$ & 11.15 & 1116.67 & 245.15 & 4733.33 & 2924.64 \\
$02-02-2017$ & 8.25 & 883.30 & 167.67 & 1567.50 & 1450.33 \\
$07-02-2017$ & 10.20 & 1966.60 & 345.67 & 2345.67 & 2345.67 \\
$10-02-2017$ & 11.10 & 2266.60 & 480.33 & 3670.67 & 2365.50 \\
$06-03-2017$ & 7.80 & 533.33 & 552.96 & 1123.33 & 3456.67 \\
$18-03-2017$ & 10.30 & 1316.67 & 1365.12 & 3400.50 & 6789.50 \\
$22-03-2017$ & 10.20 & 678.66 & 553.33 & 1234.50 & 4456.67 \\
$25-03-2017$ & 26.60 & 2234.50 & 556.67 & 11325.60 & 8325.60 \\
$26-03-2017$ & 30.90 & 3450.60 & 134050.00 & 69066.67 & 306666.00 \\
Total & & & 14057.85 & & 383988.00 \\
\hline & & & & & \\
\hline
\end{tabular}

Table 4. Result on Sediment Delivery Ratio (SDR) in landscapes with and without salak sidimpuan vegetation

\begin{tabular}{lcl}
\hline WCA & Extent (ha) & SDR \\
\hline With salak sidimpuan & 929.854 & 0.020 \\
Without salak sidimpuan & 1970.706 & 0.008 \\
\hline
\end{tabular}

The SDR value of WCA of non salak area is 0.008 which is smaller than that of salak land. The calculation of SDR suggests that the wider is the WCA, the lower is the SDR because small watersheds or WCA do not have or have little extent of flat areas, giving little resistance in sediment flow to the river basin.

The lower value of sediment in landscapes with salak sidimpuan vegetation compared to landscapes without salak sidimpuan vegetation suggests that salak plants can suppress the flow of surface runoff so that the sediment discharge into the river will be reduced. The density of rooting system of plant determines the effectiveness of the plant in assisting soil aggregate stabilization which also increases the porosity of the soil. Soil porosity is a factor determining the size and infiltration capacity as such increasing soil porosity can reduce the destructive energy of surface runoff and erosion (Ziliwu 2002). The amount of sediment transported and flowed into river is an indication of the extent of soil erosion through surface runoff. The lower is the amount of sediment, the smaller is the erosion risk. 
Donjadee dan Chinnarasri (2012) investigated the effect of rainfall intensity and slope gradient on the performance of vetiver grass mulch (VGM) for soil and water conservation. The average soil losses were $0.32-2.85 \mathrm{~kg}$ $\mathrm{m}^{-2}$ on the bare soil plots, and $0.07-1.80 \mathrm{~kg} \mathrm{~m}^{-2}$ on the VGM plots. The VGM showed good potential for reducing runoff by $31.5-68.4 \%$ and soil loss by $33.7-82.4 \%$, compared with those without VGM. The quantity of VGM equal to $0.75 \mathrm{~kg} \mathrm{~m}^{-2}$ showedthe best performance in reducing runoff and soil loss.

Vicente et al. (2013) investigated surface runoff and sediment of water catchment from hillsides to lake which shows decreasing erosion as vegetation cover increase and a decreasing number of linear landscape elements. The average erosion rates range between 1.5 and $3.7 \mathrm{ton} / \mathrm{ha} / \mathrm{yr}$ for different land use scenarios with values decreasing as the vegetation recovery in the abandoned fields increase. Silver et al. (1994) point out that porosity, water holding capacity, soil carbon, organic matter,total nitrogen $\%$, sand $\%$, and clay $\%$ were found to be high in the Asarori forest range.

Helmers et al. (2012) investigated the effectiveness of prairie filter strips (PFS) in trapping sediment from agricultural runoff. Four treatments with PFS of different size and location (i.e., $100 \%$ row crop, $10 \%$ PFS of total watershed area at footslope, 10\% PFS at footslope and in contour strips, $20 \%$ PFS at footslope and in contour strips) were arranged in a balanced incomplete block. The mean annual sediment yield through 2010 was 0.36 and 8.30 ton/ha or the watersheds with and without PFS, respectively, demonstrating $96 \%$ sediment trapping efficiency for the 4-yr study period.

The areas of West Angkola Sub-district have a very sloping land condition (slope of $65 \%-85 \%$ with length of slope of more than $300 \mathrm{~m}$ ) with mountainous topography. This condition has the potential to cause land erosion or landslide disaster. In fact, most salak farmers in East Angkola Sub-district grow salak on slopes under agroforestry system with annual crop as protective plant (Idasari 2013). Salak plants are intolerant with full irradiation and require shade plants such as durian trees and forest plants

Result of Mann-Whitney Test shows that there are significant differences in sediment values between landscapes with and without salak sidimpuan vegetation. The calculation of sediment trap in landscapes with salak sidimpuan vegetation is much lower than that without salak sidimpuan vegetation in West Angkola Sub-district. Similar result was also found in East Angkola Sub-district with the highest sediment was resulted in March (0.74 tons/day) until April 2015 (1.1 tons/day) (Nasution 2015). These results suggest that salak sidimpuan vegetation can prevent erosion and landslides as sediment in landscapes planted with this plant is quite low.

Table 5. The Mann Whitney Independent Test Results of WCA between landscapes with and without salak sidimpuan vegetation

\begin{tabular}{llll}
\hline & & Sig (2-tailed) & Evidence \\
\hline Sediment & equal & 0.000 & Significant \\
variances & & & $0.000<0.05$ \\
\hline
\end{tabular}

In general, snake fruit (Salacca spp) has strong roots and wide canopy which can withstand the rainwater. As such, these plants are among crops with soil conservation value along with other species such as palm trees (Arenga pinnata), bamboo (Gigantochloa spp.), Kaliandra (Calliandra calothyrsus, gamal (Gliricidia sepium) and rattan (Calamus spp.) (Rachman 2010). C.odorata increases soil nutrients and fallow organic matter, fallow soil is able to improve soil construction and porosity, reduce bulk density, and improve soil fertility and other invasive plant growth (Mandal and Joshi 2014). The main protected species in Tunisia include Cenchrus ciliaris, aegyp-tiaca, Echiochilon fruticosum, Helianthemum sessiliflorum, These species are important parts of arid and semiarid landscapes that pre-vent soil erosion and desertification (You et al. 2016). The next is seasonally dry oak forests in the Mixteca Alta, Oaxaca, Mexico (Santelises and Castillo 2013).

In conclusion, the interception of rain in salak sidimpuan areas in West Angkolais $76.23 \%$ of the amount of rainfall, showing higher value than interception in coffee plant $(72.12 \%)$ and tropical rainforest of $35 \%$ of total rainfall. This result suggests that salak sidimpuan plants can withstand rainfall to reduce the amount of runoff at the soil surface which can mitigate soil erosion. The amount of eroded soil in Water Catchment Areas (WCA) with salak sidimpuan vegetation with extent of 929.854 ha is 15.12 ton/ha, whereas in those without salak sidimpuan vegetation with extent of 1970.706 ha is 194.85 ton/ha. The Mann Withney test shows significant difference on the amount of erosion between WCA with and without salak sidimpuan vegetation. The low sediment values in landscapes with salak sidimpuan vegetationis likely due to the morphology of the plant which can retain rainwater through stems, midribs, leaves and roots. Based on the results of this study salak sidimpuan can be recommended as soil conservation crop by planting this plant on sloping areas as one of vegetative conservation techniques. This is an input for land use planning in the areas which are appropriate to the growing conditions of salak sidimpuan in South Tapanuli District.

\section{ACKNOWLEDGEMENTS}

We would like to express our sincere gratitude to the Directorate of Community Service Research (DRPM) Ministry of Research, Technology and Higher Education of the Republic of Indonesia who supported this study. We also would like to thank the editor and anonymous reviewer for their constructive comment on the manuscript.

\section{REFERENCES}

Anarsis W. 1996. Salak Commodities Agribussiness. Bumi Aksara. Jakarta. [Indonesian]

Arsyad S. 2010. Soil and water conservation. Bogor. [Indonesian]

Asdak C. 2007. Hydrology and Watershed Management. Gadjah Mada University, Yogyakarta.

Astuti. 2007. Cultivation of Salak. Agromedia Pustaka. Jakarta. [Indonesian] 
Basri H, Manfarizah, Salasa A. 2012. Interception of Rain Water at the People's Coffee Plant in Kebet Village, Bebesan District, Central Aceh District. Jurnal Floratek 7: 91-106. [Indonesian]

Boyce RC. 1975. Sediment Routing with Sediment Delivery Ratios. In. Present and Prospective Technology for Predicting Sediment Yields and Sources. US Dept. Agric. Publ. ARG S-40, 61-65.

Dinata, R J. 2007. Interception In Various Grades of Rubber Standing Age (Hevea brasiliensis). [Thesis]. Department of Forestry, Faculty of Agriculture, Unoversitas Sumatera Utara, Medan. [Indonesian]

Dohnal M, Cerny T, Votrubova J, Tesar M. 2014. Rainfall interception and spatial variability of throughfall in spruce. stand. J Hydrol Hydromech 62 (4): 277-284.

Donjadee S, Chinnarasri C. 2012 Effects of rainfall intensity and slope gradient on the application of vetiver grass mulch in soil and water conservation. Intl J Sediment 27 (2): 168-177.

Gaira KS, Rawal RS, Singh KK. 2016. Variations in pollinator density and impacts on large cardamom (Amomum subulatumRoxb.) crop yield in Sikkim Himalaya, India. J Asia-Pacific Biodiv 9: 17-21.

Helmers MJ, Zhou X, Asbjornsen H, Kolka R, Tomer MD, Cruse RM 2012. Sediment removal by prairie filter strips in row-cropped ephemeral watersheds. J Environ 41 (5): 1531-1539.

Idasari. 2013. Classification of salak-based agroforestry system in Kabupaten Tapanuli Selatan. Jurnal Ilmu Pertanian Kultivar 7 (1): 151. [Indonesian]

Kaushal R, Kumar A, Alam HM, Mandal D, Jayaparkash J, Tomar JMS Patra S, Gupra AK, Mehta H, Panwar P, Chaturvedi OP, Mishra PK. 2017. Effect of Different canopy management practices on rainfall partitioning in Morus alba. J Ecol Eng 102: 374-380.

Kironoto BA, Yulistiyanto B. 2000. The simplified of suspended sediment measurement method for predicting suspended sediment load as a basic of reservoir capacity design as renewable energy resource. Intl J Renew Energ Res 6 (1): 315-322.

Mandal G, Joshi SP. 2014. Invasion establishment and habitat suitability of Chromolaena odorata (L.) King and Robinson over time and space in the western Himalayan forests of India. J Asia-Pacific Biodiv 7 : 391-400.

Nasution Y. 2015. Effectiveness of sediment trap at salak sidimpuan sentra estate in South Tapanuli. Jurnal Pertanian Tropik 2: 187-199. [Indonesian]

Rachman E. 2010. Planting Planning for Forest Rehabilitation and Degraded land in West Java. Prosiding Dialog Stakeholders. [Indonesian]

Rey F. 2003. Influence of vegetation distribution on sediment yield in forest merely gullies. Catena 50 (2-4): 549-562.
Santelises RA, del Castillo RF. 2013. Factors affecting woody plant species diversity of fragmented seasonally dry oak forests in the Mixteca Alta, Oaxaca, Mexico. Revista Mexicana de Biodiversidad 84: 575-590.

Setyawan SF. 2010. Study of level of critical salak land Salacca Zalacca in the village of Wonorejo Karanganyar. [Thesis]. Faculty of Agriculture, Universitas Sebelas Maret, Surakarta. [Indonesian]

Silver WL, Scatena FN, Johnson H, Siccama TG, Sanchez MJ. 1994. Nutrient availability in a montane wet tropical forest: Spatial patterns and methodological considerations. Plant Soil 164 (1): 129-145.

Siregar HH, Murtilaksono K, Sutarta ES. 2006. Analysis of palm oil plant interception. Palm Oil Res J 14: 83-90.

Tapsel. 2015. South Tapanuli in Figures. Badan Penyuluhan Pertanian dan Ketahanan Pangan Kabupaten Tapanuli Selatan, Sipirok. [Indonesian]

Thomas J, Joseph S, Thrivikramji KP. 2018. Estimation of soil erosion in a rain shadow river basin in the southern Western Ghats. India using RUSLE and transport limited sediment delivery function. Intl Soil Water Conserv Res 6: 111-122.

Vicente ML, Navas A, Gaspar L. 2013. Predicting runoff and sediment connectivity and soil erosion by water for different land use scenarios in the Spanish Pre-Pyrenees. Catena 102: 1-82.

Widjajadi BW. 2010. Erosion anchoring plant tipology: Case study in teak forest. Agrovigor 3 (1): 77-86. [Indonesian]

Xiao Q, McPherson EG, Ustin SL, Grismer ME, Simpson JR. 2000. Winter rainfall interception by two mature open-grown trees in Davis, California. Hydrol Proc 14: 763-784.

Xinxiao Y, Henian W, Zhongbao X, Xizhi Lv. 2013. Effect of forest on sediment yield in North China. Intl Soil Water Conserv Res 1 (1): 5864.

Yan R, Zhang X, Yan S, H Chen. 2018. Estimating soil erosion response to land use/cover to change in a catchment of the loess Plateau China. Intl Soil Water Conserv Res 6: 13-22.

You H, Jin H, Khaldi A, Kwak M, Lee T, Khaine I, Jang J, Lee H, Kim I, Ahn T, Song J, Song Y, Khorchani A, Stiti B, Woo S. 2016. Plant diversity in different bioclimatic zones in Tunisia. $\mathrm{J}$ Asia-Pacific Biodiv. DOI: 10.1016/j.japb.2016.01.002.

Zachar, D. 1982. Soil Erosion. Elsevier, Bratislava, Czechoslovakia.

Zhang Y, Wang X, Hu R, Pan Y, Paradeloc M. 2017. Rainfall partitioning into throughfall, stemflow and interception loss by two xerophytic shrubs within a rain-fed re-vegetated desert ecosystem, northwestern China. J Hydrol 527: 1084-1095.

Ziliwu Y. 2002. The Influence of Some Plants to Surface Flow and Erosion. [Thesis]. Graduate Program, Diponegoro, University Semarang. [Indonesian] 